\title{
Community perceptions and response to flood risks in Nyando District, Western Kenya
}

Hellen Nyakundi

Liaison Officer, Food Link

Nairobi, Kenya

hmnyakundi@yahoo.com

Stephen Mogere

Development Evaluation Expert

Nairobi, Kenya

snmogere@gmail.com

Isaac Mwanzo

Kenyatta University

Nairobi, Kenya

Isaac.Mwanzo@ku.ac.ke

Andre Yitambe

Department of Public Health, Kenyatta University

Nairobi, Kenya

Andre.Yitambe@ku.ac.ke

\section{ABSTRACT}

In Kenya, the ability of local people to resist the impact of disasters has not been given adequate attention. A descriptive cross sectional study sought to investigate community perceptions and responses to flood risks in low and high risk areas of the Nyando District, Western Kenya. A total of 528 households, six government officials and five project managers of Community Based Organizations (CBOs) and Non Governmental Organizations (NGOs) were interviewed. Additionally, seven Focus Group Discussions (FGDs) involving three women, two male and two teacher groups were conducted. Data were analysed using the Statistical Package for the Social Sciences (SPSS) Program. The Chi-square test was used to determine associations and differences between variables. In the study, $83 \%$ of the respondents were aware of Traditional Flood Knowledge (TFK) and 80\% acknowledged its use. Perception of the risk is influenced by several variables, most notably past experience of major floods and having survived them. Residents in the high risk areas had significantly higher levels of awareness and use of traditional flood knowledge. They were more aware of the nature of the flood related health risks they were exposed to and appeared better prepared for future flood risk. They were, however, more dependent on external aid. On the other hand, residents living in the low risk area reported better success with their response mechanisms.

\section{KEYWORDS}

Flood Risk Perception, local coping capacity 


\section{Introduction}

In Kenya, many parts of the country experience unexpectedly heavy rainfall in mid-April which continues through to the end of May (the long rains) and from September to November (the short rains). The areas that are most prone to flood disasters are the Lake Victoria Basin, comprising the Bundalang'i floods in Western Kenya, along the Nzoia River with the flood waters arising from the Chelangani Hills and the Kano Plain Floods along the Nyando River with the flood waters arising from the Nandi Hills; the Tana River floods along the downstream areas along the river with flood waters originating from the Aberdares and Mt. Kenya catchments (Kenya, 2006/7:6). Much of the existing literature on flood management in Kenya has explored the physical aspects of their nature and occurrence (Mbaria, 2006; Mungai et al., 2004; Wanjohi, 1999; Adegu, 1999; Njogu, 2002; Onyango et al., 2005). However, there is also a growing literature that is examining the issue from a social perspective with calls in particular for more research into the social responses to flood management (Ongor, 2007; Mwaura, 2008; JICA, 2007).

The Nyando River Basin covers an area of 3500 square kilometres in Western Kenya. About 750,000 persons reside within the Nyando Basin, most of whom live in the Nyando District in Nyanza Province and the Nandi and Kericho districts in the Rift Valley Province. The incidence of consumption poverty is high, ranging from an average of $58 \%$ in Kericho District, 63\% in Nandi District and 66\% in Nyando District. At the administrative location level, the locations of Nyando District include both those with the lowest poverty rate in the sugar belt of Muhoroni Division (36\%) and the highest poverty rate in the Upper Nyakach Division $(80 \%)$ in the entire basin (Central Bureau of Statistics, 2003). HIV / AIDS prevalence varies between 28\% in Nyando District, 7\% in Nandi District, and 12\% in Kericho District (Swallow et al., 2005:6; Ongor, 2007:2).

The catchment has a steep gradient upstream but a gentle one downstream in the Kano plains where the river dissipates in a wetland area and finally discharges into the Nyakach Bay, Lake Victoria. Over 5,000 people are affected every year by floods in the area. This generally happens during the long and short rains, especially after spells of intense and heavy rainfalls in the catchments of the rivers. The upper reaches of Nyando are in the Kericho and Nandi Districts where the annual rainfall is high and it is this rain that causes the most devastating of the floods in the basin. The average annual damage is about US\$ 850,000 with annual relief and rehabilitation measures costing US\$ 600,000 in the Kano Plains (Eitel \& Ochola, 2006:1).

Major floods documented in the area occurred in 1937, 1947, 1951, 1957-1958, 1961, 1964, 1985, 1988, 1997-1998, 2002 and 2003 (Ongwenyi et al., 1993:118-119; Eitel \& Ochola, 2006:1). The El Niño related floods of 1997/8 constituted one of the greatest flood episodes experienced in Kenya in recent years. The land degradation peaked during the heavy rains associated with El Niño events, of which there have been three in the Nyando over the past century. However, Nyando Basin continues being flooded every year during the long (AprilJune) and short (October-November) rainy seasons (Njogu, 2002:2; Otiende, 2009:4). The frequency of heavy precipitation events has increased especially in areas near Lake Victoria that experience warming and increases of atmospheric water vapour (Kenya, 2006/7:6; Miller, 2009:10; IPCC cited in Otiende 2009:2). The study site was selected because about 258,738 


\section{Fig 1. Nyando Flood Contingency Planning Map (14 ${ }^{\text {th }}$ October, 2009)}

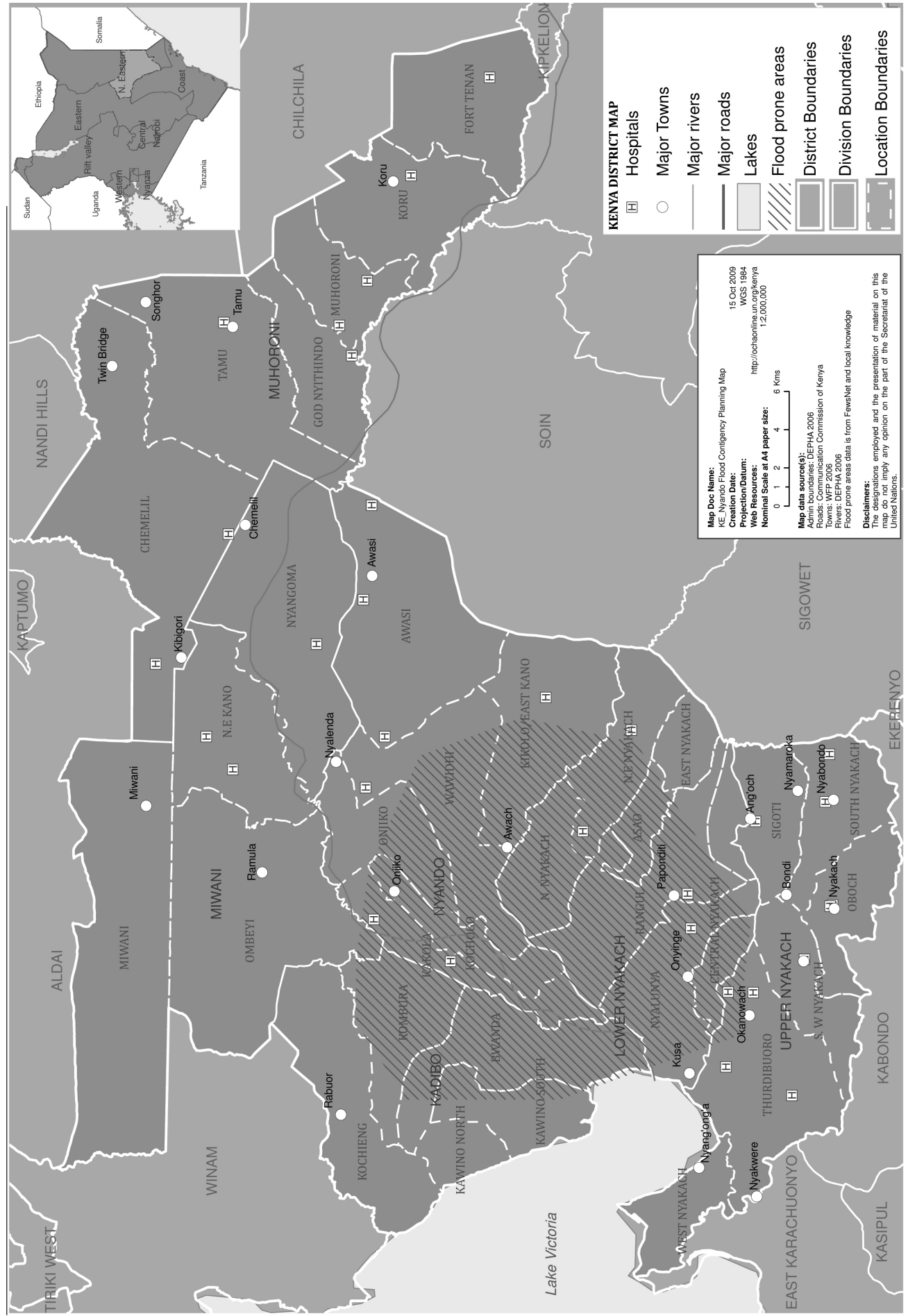

Source: United Nations Office for the Coordinating of Humanitarian Affairs (OCHA) bttp://www.nyando.org/about/ nyandofloodmap.pdf 
people (35\%) of the population in Nyando River Basin reside in the Nyando District (Mungai et al., 2004:22). It has a geographical coverage of $1,168.4 \mathrm{~km}^{2}$ (Ministry of Finance and Planning, 2002:4) and is divided into five administrative divisions: Upper Nyakach, Lower Nyakach, Nyando, Miwani and Muhoroni1. The district lies in the eastern part of the large lowland surrounding the Nyanza Gulf, much of it being in the Kano Plains. The topography can be generally classified into three land formations: the Nandi Hills, the Nyabondo Plateau, and the Kano Plains which are sandwiched between the hills. The Kano Plains comprise predominantly black cotton clay soils with moderate fertility and poor drainage. The rest of the district has sandy clay loam soils derived from igneous rocks. The district has a population of 357,393 (2005 projection) (Ministry of Finance and Planning, 2002:4). The area supports a large rural population ( 75 per cent) and the stage of economic growth is undermined by high absolute poverty levels, deteriorating infrastructure and the HIV pandemic (Swallow et al., 2005:6; JICA, 2007:128-150). The settlement patterns are mainly determined by the potential of the area; Upper Nyakach division has the highest population density with nearly 368 persons per $\mathrm{km}^{2}$, while Muhoroni is the least populous with about 190 individuals per $\mathrm{km}^{2}$. Muhoroni division is a high potential sugar-belt region, and is also the largest division in the district, covering an area of $334.8 \mathrm{~km}^{2}$. The average density of the district is 284.6 people per $\mathrm{km}^{2}$ with an annual growth rate of $3.4 \%$.

Floods are experienced in the lower course of the Nyando River covering approximately 50\% of the Nyando district. This is the region geographically referred to as the Kano Plains (Mungai et al., 2004:43). The flat terrain of the Kano Plains does not allow easy drainage of water into the waterways.

As a result of this, rainwater tends to remain on the land for considerably longer periods than would be the case where the gradient is steeper. The Black Cotton soils (Vertisols) found in the Kano Plains do not allow quick infiltration of surface water into the ground. This compounds the problem of drainage since surface drainage is already impeded by the gradient (Omuto cited in Mungai et al., 2004:44). Erosion as a result of inappropriate land use in the watershed and the flood plains leads to an increase in the sediment load of the river. The sediments fill up the channel in the lower course of the river where its speed is reduced by the gentle gradient. The channel's capacity to hold water is thus reduced and it becomes unable to hold the waters flowing through by the river and this leads to flooding. The upper reaches of the Nyando are in the Kericho and Nandi districts where annual rainfall is high and it is this rain that causes the most devastating of the floods in the basin. Reduced vegetation cover in the watersheds leads to less rainwater percolating into the soils, thus increasing surface run off which causes flash floods. The implication is that for the duration of the flash flood, the river channel is supplied with an unusually high volume of water, which it is not able to contain, thus causing floods (Omuto cited in Mungai et al., 2004:44).

Flooding in the Nyando District is a rapidly growing public health problem in the area. Perennial water overflow has caused extensive erosion in the Lower Nyakach and Miwani divisions resulting in huge gullies such as Katuk Ondejo in Lower Nyakach. Floods have increased the incidence of a number of water associated diseases among people and animals, 
constrained crop and tree selection, made transportation more difficult, interrupted schooling and destroyed property and infrastructure (Ministry of Finance and Planning, 2002:2). The residents of these flood-prone areas suffer every year due to damage caused by the floods. It should be noted that the small and medium size floods that occur perennially in the Nyando District have an equally devastating accumulative effect with annual damages of $>49$ million (Ksh) and annual relief and rehabilitation of $>37$ million (Ksh) (Otiende, 2009). The impacts of these extreme climatic events intertwined with socio-economic constraints have made populations living in these areas even more vulnerable. Furthermore, since independence, this part of Kenya has been marginalised in terms of investments by the central government and economic resources for expanding flood control.

The limited intervention for disaster risk reduction has consisted mainly of conventional methods such as structural techniques and the provision of relief. These are well reported and understood. What have been largely ignored are the local perceptions, experiences and historical processes that have been used to mitigate floods by the community. The people living there have been settled for many hundreds of years and share a uniform linguistic and cultural background, making it easier for deep local knowledge and coping strategies to emerge and be transmitted from generation to generation. However, the ability of the local people to resist the impacts of flood disasters has not been given prominence.

This paper therefore explores perceptions and coping strategies to deal with flood impacts adopted by local communities within the flood prone regions of the Nyando District, Western Kenya. Explored are significant issues related to Traditional Flood Knowledge (TFK) and early warning systems, flood experience, socio-demographic, cultural and economic factors and external support.

\section{Materials and methods}

The research adopted both quantitative and qualitative techniques using pre-tested household questionnaires, desk reviews, focus group discussions and in-depth individual discussions for key informants. A sample of 528 households was interviewed; six selected government officials and five project managers of CBOs and NGOs were interviewed through key informant interviews. Additionally, seven focus group discussions involving three women, two males and two teacher groups were conducted.

Given the very large size of the District, areas of study were selected using a multi-stage sampling process. In view of the important role of institutional factors in influencing community responses, the administrative ladder of division and location and sub-location was used to select the study sites. Considerations were applied on the basis of meteorological information on the extent of flooding, a literature review and discussions with the village elders on area's history of flooding, close proximity to the river, low altitude of the area and type of settlement (high population densities). The final selected areas of study were based on high-prone and low-prone categories. The high risk locations identified were Wawidhi, Ombeyi and North East Nyakach while the low risk areas were Kochogo/Onjiko, N. East Kano and North Nyakach. 
The river basins cover an area of 3517 square kilometres of Western Kenya and have about 258,738 (35\%) persons from the Nyando District residing within them (Mungai et al., 2004: 23). The sample size for all the sub-locations was computed using the Fisher formula:

$$
n=Z^{2} p q D / d^{2} \text { (Mugenda \& Mugenda, 1999:43-44) }
$$

Where, $\mathrm{n}=$ the sample size

$Z=$ the standard normal deviate (1.96), which corresponds to $95 \%$ confidence interval

$p=$ persons living in Nyando District at risk of flooding $=258,000$

$q=$ total population in Nyando District $(332,137)$ - residents at risk of flooding

$d=$ the degree of accuracy $=0.05$

$D=$ heterogeneous population (most prone and medium prone) $=2$

Thus, $n=\left(1.96^{2 *} 0.22^{*} 0.78\right) 2 / 0.05^{2}=528$

In the process of identification and selection, respondents were divided into two groups: flood area residents, in order to analyse perceptions and response from the perspective of local citizens, and institutional representatives chosen in order to analyse perceptions and response from the perspective of decision makers and their respective institutions. Simple Random Sampling procedure was used to identify households selected to participate in the interview. Subjects were predetermined by a quarter sampling system to capture the two categories (male and female) of interest.

The sample size was further calculated using Stratification and Proportional Sampling and calculations based on total number of households in each division (Nyando, Miwani and Lower Nyakach). This technique was used to assure representation on the relative size of the different strata.

\section{Results - Key findings}

\section{Demographic and socio-economic characteristics}

Respondents of all ages (18 through to over 60 ) were represented, with slightly larger numbers in the lowest-age-bracket 18-25 and the 41-50 categories accounting for $117(22.1 \%)$ and $116(22 \%)$ of the respondents, respectively. The oldest age bracket was 60 and above years which accounted for $71(13.5 \%)$ of the respondents. The number of males interviewed was smaller at 231 (43.8\%) compared with females at 297 (56.2\%). This can be attributed to the fact that most male household members were engaged in outdoor work during the survey period.

The findings of this study showed that most of the respondents, namely 353(66.9\%) were married and living with their spouses. A further $114(21.1 \%)$ were widowed, $56(8.6 \%)$ were single, while $0.8(1 \%)$ were divorced. Female-headed households, widows/widowers and their children were generally perceived to be more vulnerable to floods as compared with their 
Fig 2. Map showing high and low flood risk areas sampled during the study in Nyando

\section{NYANDO DISTRICT}

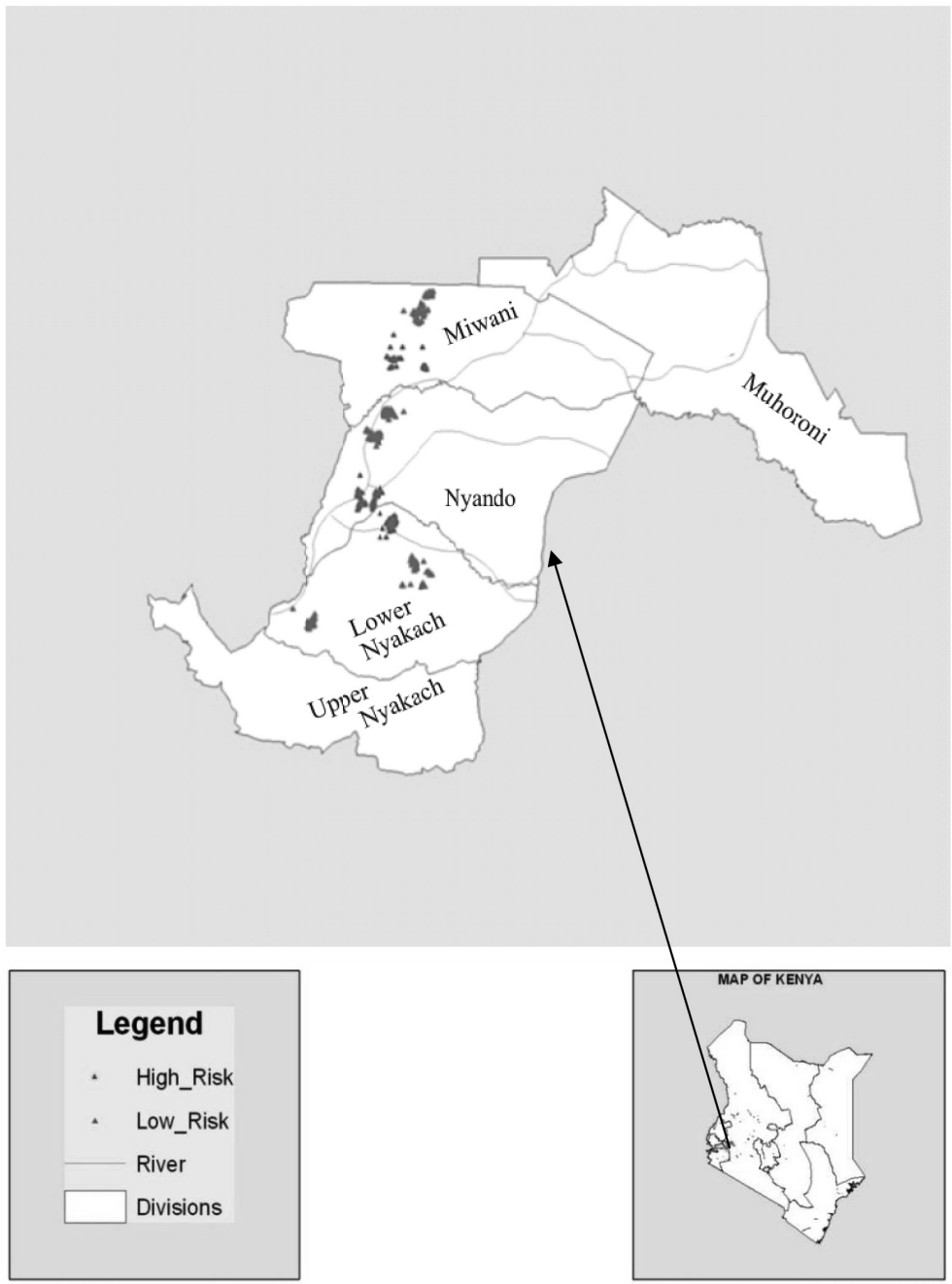

Map data source: Hellen Nyakundi

counterpart households with both spouses. This could be explained by the fact that households with both spouses are better placed both financially and psychologically. They are therefore able to respond to flood risks in a better mental and emotional state than their single counterparts (SERA Project, 2000:203; Yamano \& Jayne, 2002:7-11). However, this is not necessarily true in this case study as shown by the losses experienced by the majority of the households despite the fact that most of them had both spouses alive at the time of this study. Our analysis revealed no significant difference between marital categories and loss experienced in both high and low risk areas. 
The relationship between household resources and flood vulnerability is that coping with and recovery from flood impacts both demand financial reserves that can buffer the household from negative flood impacts (Nethengwe, 2007:117; SERA Project, 2002:77-78). The study findings indicate a high degree of poverty and low incomes reflected in the employment types where the majority of the people were in the informal sector. The main occupation of a majority, namely 365 respondents (67.1\%) was subsistence farming. A smaller proportion 76 (14.4\%) consisted of skilled and unskilled artisans composed of carpenters, mechanics shop owners, fishermen and vegetable vendors while a mere 19 (6\%) respondents were employed. The remaining 68 (12.9\%) were grouped under the unemployed category and these included the jobless, students and housewives. The modal monthly gross family income for $380(70 \%)$ of the households was below 2,500 KSh (less than a dollar a day, putting them below the poverty line). The results are consistent with the national statistics that indicate high absolute poverty levels (67\%) in the Nyando District, based on the 1999 census (Ministry of Finance and Planning, 2002:7).

In general, the findings showed that $99(18.8 \%)$ of the respondents had not gone to school at all and an overwhelming $86(86.9 \%)$ in this category were women. Only a quarter $129(24.5 \%)$ of the participants had gone beyond primary level and, among these, $124(23.5 \%)$ had completed secondary education while 17 (3.3\%) had some post-secondary education. The low levels of education could be attributed to high poverty levels and lack of motivation to pursue higher education. The low-income levels among the study population and especially the females may be attributed to low levels of education with only 41 (13.9\%) having gone beyond primary level. Low education levels have been associated with lack of well-remunerated employment and therefore less social power and fewer economic resources and physical capacity to anticipate, survive and recover from the effects of massive floods (ISDR, 2004:42).

A significant 71 (29\%) of the women had no formal education as compared with 13 (5\%) of their male counterparts. Further results showed that $77.5 \%$ of female income per month fell in the $<2,500 \mathrm{Ksh}$. category and therefore many women had to depend on their spouses or relatives for a livelihood. These circumstances have been found to affect the women's ability to respond appropriately to flood hazards as well as their capacity to participate in flood management at both household and community levels (Wiest et al., 1994:13; Cannon, 2000:43-55; Few et al., 2004:25; Bhatti, 2001:16).

The study established that well/boreholes 238 (45.1\%) followed by rivers/streams 148 (28\%) were the major sources of water both for drinking and domestic use. A significant 140 (94.6\%) of river/stream users lived in the high risk areas. Slightly below a quarter $142(24.2 \%)$ had access to communal, piped tap water. Further discussions established that access to clean piped water was a major problem and further diminished during the flood season. During the flood season $88 \%$ of those who used rivers as their main source reported shortage of clean water as compared with $54 \%$ of those who relied on boreholes/wells and $31 \%$ of those who had access to communal tap water. 
It was observed that a high proportion 449 (89.0\%) of the wall structures were made of mud. Nearly $47(8.9 \%)$ of walls were made of stone or brick, while a smaller proportion $5(1 \%)$ were of timber. A mere 7 (1.3\%) of the walls were constructed with mats and reeds in both risk levels. Results further indicate that a huge proportion $442(83.2 .9 \%)$ of the house structures had iron sheet roofing whilst a mere $68(12.9 \%)$ and $17(3.2 \%)$ had their roofs thatched with grass and Makuti (reeds), respectively. Nethengwe (2007:126-130) emphasises that the housing quality index is an important indicator of flood vulnerability. For example, in his study, households in a grass-thatched house were perceived to be more vulnerable to floods than a household in a stone house, whose housing structure represents high coping capacity and more resilience to flood hazards.

Table 1: Summary of traditional early warning flood indicators (Multiple answer response)

\begin{tabular}{|c|c|c|c|c|c|}
\hline \multirow{2}{*}{$\begin{array}{l}\text { Traditional Knowledge } \\
\text { Behaviour of humans, } \\
\text { plants and animals }\end{array}$} & \multirow[t]{2}{*}{ Indicators } & \multicolumn{2}{|c|}{ Low risk } & \multicolumn{2}{|c|}{ High risk } \\
\hline & & Freq. & $\%$ & Freq. & $\%$ \\
\hline & Old people's bones aching & 28 & 12.2 & 43 & 17.1 \\
\hline & $\begin{array}{l}\text { Large numbers of cow } \\
\text { egrets sited }\end{array}$ & 32 & 13.9 & 34 & 14.2 \\
\hline & $\begin{array}{l}\text { Loud persistent croaking } \\
\text { of frogs }\end{array}$ & 17 & 7.3 & 35 & 14.6 \\
\hline & $\begin{array}{l}\text { Domestic animals making } \\
\text { loud distraught noises }\end{array}$ & 1 & 0.4 & 1 & 1.7 \\
\hline & $\begin{array}{l}\text { Movement of ants to } \\
\text { higher ground }\end{array}$ & 0 & 0 & 10 & 4 \\
\hline \multicolumn{6}{|l|}{$\begin{array}{l}\text { Knowledge of weather } \\
\text { pattern }\end{array}$} \\
\hline & $\begin{array}{l}\text { Heavy rains in the area for } \\
\text { long periods of time }\end{array}$ & 109 & 45.6 & 133 & 54.5 \\
\hline & Heavy rains in Nandi Hills & 87 & 35.7 & 114 & 47.7 \\
\hline & $\begin{array}{l}\text { Lightning and thunder on } \\
\text { the river }\end{array}$ & 30 & 12.3 & 42 & 17.6 \\
\hline & $\begin{array}{l}\text { Temperatures higher than } \\
\text { usual }\end{array}$ & 29 & 11.9 & 31 & 13 \\
\hline & $\begin{array}{l}\text { Strong winds blowing from } \\
\text { river to the hills }\end{array}$ & 20 & 8.2 & 30 & 12.6 \\
\hline \multicolumn{6}{|l|}{$\begin{array}{l}\text { Knowledge on nature } \\
\text { of river }\end{array}$} \\
\hline & Rising of the river & 66 & 27 & 123 & 51.5 \\
\hline & Debris in the river & 34 & 14.2 & 139 & 58 \\
\hline & $\begin{array}{l}\text { Noise level of river } \\
\text { increases }\end{array}$ & 18 & 7.4 & 33 & 13.9 \\
\hline & River turns dirty brown & 4 & 1.6 & 23 & 9.6 \\
\hline \multicolumn{6}{|l|}{$\begin{array}{l}\text { Knowledge of flood } \\
\text { cycles }\end{array}$} \\
\hline & Knowledge of seasons & 0 & 0 & 5 & 2 \\
\hline & Knowledge of flood cycles & 0 & 0 & 4 & 1.5 \\
\hline
\end{tabular}




\section{Traditional knowledge on flood forecasting}

In the study, (482 or 83\%) of the respondents were aware of local ways of knowing whether it would flood or not and (465 or $80 \%$ ) of these respondents acknowledged the use of the traditional knowledge to predict the flooding risk. These results demonstrate that local strategies are considered as a trusted source of information and of importance to this community.

Results from the study further indicate a significant difference between level of awareness of traditional knowledge in the high and low risk areas $\left(\mathrm{X}^{2}=; 11.526 \mathrm{df}=1 ; p=.001\right)$ with a considerably larger proportion of respondents in the high risk areas being more aware of traditional flood knowledge than those residing in the low risk areas. The most likely explanation for the difference is flood experience. This supports observations by Slovic et al. (1979:14-36) who concluded that people's level of flood experience and their place of residence had an important impact on levels of flood awareness.

Discussions with the focus groups further revealed that the majority of the young people did not have a good command of traditional flood knowledge (TFK). This could be attributed to their inexperience/not being old enough to gather all TFK. This did not seem to bother them because they argued that TFK was outdated and there were better and more modern methods of predicting floods.

These findings match those of Bhatta (1999:24-25), which acknowledges that local knowledge lacks accountability within communities themselves, especially with the younger generations; the dominant belief being that conventional or scientific knowledge is 'superior' to local knowledge.

It is generally accepted that TFK is in many cases preserved as oral tradition and is passed on by word of mouth. The study findings contradict this as only $163(38 \%)$ of the respondents received this information from their elders. A huge proportion, namely $357(73.8 \%)$ reported getting most of their flood information mainly through personal observation. This has been attributed to formal education and the decreasing traditional practice of passing on early warning strategies by word of mouth.

As regards the current official flood warning systems, participants were generally not satisfied because the information received from the local administrators was considered common knowledge. The information concentrated on flooding zones but not what to expect. They also acknowledged that it was difficult to accurately predict flash floods using scientific methods and that is why they relied more on traditional alerts.

\section{Demographic influence on traditional flood knowledge}

The results in the study revealed an association between age, occupation and length of residency with awareness and use of traditional flood knowledge. The association between the two demographic variables, age and length of residency and traditional flood knowledge was found to be highly significant at $0.000-1$ only in the high risk areas. The highest proportion of respondents with traditional flood knowledge were in the $33+$ age groups who had lived in the 
flood prone area for more than four years. This could derive from a life spent in flood prone areas and the greater chance that older people have the benefit of more flood experience. The results are similar to those of a survey carried out on flood victims of the 2002 Melde Flood in Eilenburgh (Kuhlicke, 2006:14) in which respondents with extensive local flood knowledge were those who had lived in the area for a long time and had experienced major floods.

As regards occupation and income, farmers were more aware of traditional flood knowledge than the rest of the categories. Differences in awareness of the information within the occupation categories were found to be significant in both high $\left(\mathrm{X}^{2}=; 47.309 \mathrm{df}=21 ; p=.001\right)$ and low risk areas $\left(\mathrm{X}^{2}=; 40.866 \mathrm{df}=21 ; p=.006\right)$. A significant number of the responses were related to agricultural coping measures because the majority of households engaged in crop production suffer loss of standing crops. These results imply that people whose livelihoods are directly affected by flooding have more use for the local flood knowledge which they apply to minimise loss. More than $70 \%$ of households in both risk levels were poor and as a result income difference was not statistically significant

\section{Perception of flood risks}

General findings from the study revealed that the degree of perceived risk of flood threats to health was significantly higher among the respondents living in the high risk areas compared with those in the low risk areas. The demonstrated difference in perceptions is undoubtedly attributable to the level of awareness of risk and the degree of exposure to the health hazards. A similar perception of flooding has been described by Olczyk (2004:117). The memorability of past floods also leads to heightened perceptions of risk which implies that the respondents perceived risks from flooding only to the extent or magnitude that they had previously experienced. Similarly, Slovic et al. (1979:14-36) concluded that the memorability of past events played an important role in the determination of how individuals perceive and react to future flood events, thus leaving themselves vulnerable in the event of a larger flood..

Results from this study also indicated that for this community, the advantages of living close to the river far outweighed the health risks associated with flooding. Although flooding was viewed as a recurring problem, a large segment of the people interviewed 437 (82.8\%) were reluctant to permanently vacate their flood-prone land. This implies that for this community, despite the inherent flood risk, it also determines their immediate economic survival. The problem is often not simply a lack of awareness, but rather assessments of local risk based on experience that underestimate the impact of accumulating risk (Few et al., 2005:18). There is an apparently low perception as regards to the accumulated flood risk to health.

\section{Perception of management of risks}

Despite the recurrent nature of the flood hazard, results showed that flood events were perceived to be inevitable and fairly unpredictable, especially in the high risk areas, limiting scope for action and response. This might relate to the nature of the flash floods and lack of possibilities to prepare for the hazard. It could also point to increased vulnerability that could be attributed to climate change, thereby reducing the community's ability to precisely predict and warn of future flood events (Salick \& Byg, 2007:11). 
Regarding flood control measures, flood preventive measures were elected as a priority in both high and low risk areas and flood risk was perceived to be controllable with structural measures although these measures were perceived to require huge investments to implement. When asked directly, most respondents mentioned the dyke currently under construction to be the main reason that the incidence of flooding had reduced in the area. These results display a growing belief and dependency on the technical approach. This is noteworthy as a number of studies on risk perception (Kundzewicz, 1999:567) have indicated that an excess of confidence in the structural alternative performance in reducing flood frequency may bias the decisionmaking process and eventually lead to an inadequate occupation of flood prone areas, increasing flooding potential impacts in the event of structural failures. This suggests that it is not practical to reduce flood disasters only by structural measures under the concept of need to control, because this method has physical and financial limitations.

The need to attribute disasters to some supernatural force was obviously still felt by a substantial $129(24 \%)$ number of respondents. Other researchers shed more light on these views by stating that there are multiple interpretations of risks and disasters, yet the divine element is dominant. People do recognize other tangible and structural factors involved in disaster, and relating disaster to natural forces is not just a religious expression, but rather reflects the social meanings of harm happening at certain points in time and space (Bhatti, 2001:7; Salick \& Byg, 2007:19).

\section{Demographic influence on risk perception}

Differences in occupation categories indicated that small and large scale farmers perceived significantly higher levels of threat than the other occupation categories. This could be due to huge losses being incurred through the loss of crops and livestock and as a result directly affecting livelihoods.

\section{Behaviour associated with flood management}

Nearly $96 \%$ of the respondents reported their recent flood experience had occurred in years 2002 and 2003 (5.8\%), 2004 (28.4\%), 2005 (47.2\%) and the most recent in 2006 (9.5\%). The six emergency flood risks and their response measures considered in this study were damage to shelter, loss of crops, shortage of food, loss of livestock, prevalence of disease and death. Overall results from the study on these key household practices revealed notable measures to avoid negative flood effects.

A considerably high percentage of respondents reported damage to their shelter in both high $222(85.7 \%)$ and low risk areas 115 (46.7\%). Traditionally, Luo houses are built from mud and thatch. These are susceptible to damage by heavy rain, wind and flooding. Respondents seemed to understand the limitations of these housing materials but few could afford to build concrete houses with cemented walls. To prevent flood waters entering their homes, it was observed that all homesteads had houses built on raised land. The walls and entrances were also elevated. To protect their homes and farms, a huge majority dug trenches around their compounds and planted trees and sisal fences around the homesteads to break and reduce the flow of flood waters and to prevent erosion. These results reflect other studies of a similar kind done in flood prone locations (ITDG-Bangladesh, 2003:3; Few et al., 2005:16) in which housing techniques were adapted according to the risk posed by floods and erosion. 
Further findings show that during extreme flood events, affected families vacated their homes and moved to camps or were accommodated by relatives and friends. We established that those who were accommodated in temporary flood shelters put up by the government and NGOs received the most assistance whereas the majority of those accommodated by neighbours and relatives received little assistance. This was because it was difficult to coordinate relief to the scattered households. In a similar study, Gaston (2005-2006:13) in his study on flood risk management in Tanzania reported that flood victims always moved back to their damaged houses and their safety remained a concern because the structural stability of the houses was unknown. There was also the likelihood of contracting diseases due to lingering stagnant water.

Respondents reported food and water shortages during the flood season. The study indicates that the households had to reduce the quantity of food eaten or skip some meals, or borrow money and food in order to survive through the flood season. Most people borrowed money from informal sources like relatives, neighbours and friends. Quite a good number of households looked for alternative employment to substitute income. In extreme conditions some households traded their assets for money and food. Reducing food intake, and borrowing and selling of assets by families in distress are coping strategies that have been mentioned in findings of other researchers (SERA Project, 2000:187-195; Sharma, 2002:3). To deal with the water shortages, households boiled water $127(41 \%)$, harvested rain water $110(35 \%)$ or used purifying tablets 91 (29\%).

In the survey, an average $93.8 \%$ of the respondents identified flooding as having resulted in the prevalence of disease and ill health in their households whilst the rest $(6.2 \%)$ had no such incidence.

Table 2: Summary of diseases suffered by respondents during the flood season

\begin{tabular}{|l|c|c|}
\hline Disease & Low risk area (\% ) & High risk area (\% ) \\
\hline Malaria & 90.8 & 92.9 \\
\hline Typhoid & 12.8 & 29.1 \\
\hline Cholera & 13.2 & 25.2 \\
\hline Dysentery & 15.1 & 21.3 \\
\hline Fever & 10.1 & 24.4 \\
\hline Pneumonia & 11.9 & 17.3 \\
\hline Vomiting & 4.6 & 16.5 \\
\hline Athlete's foot & 5.0 & 11.4 \\
\hline Skin diseases (Others) & 4.6 & 7.1 \\
\hline Bilharzia & 3.2 & 8.3 \\
\hline Amoeba & 2.5 & 5.5 \\
\hline
\end{tabular}


Malaria was the single most commonly mentioned flood-related disease. Even though it is endemic in the region, it was reported to be more prevalent during and immediately after the flood season. The mosquito-borne disease is related to favourable breeding conditions for mosquito larvae created by stagnant flood waters (Few et al., 2005:15).

Interviewees strongly associated flooding with increased incidences of cholera, typhoid, dysentery, amoeba and fungal skin disease. The district public health officer claimed few cases of cholera had been reported in the district but in the study it was ranked second after malaria. It was observed that almost all households had shallow and temporary pit latrines that easily fill up during the rainy season. This is the most probable way that diarrhoeal diseases spread since the faeces could easily have found their way into water sources such as wells, unprotected springs and rivers. Fungal skin disease, in particular athlete's foot, could be associated with respondents being constantly in contact with flood waters when performing domestic chores. This results are similar to those of Mungai $e t$ al. (2004:51-52) in which malaria epidemics were found to occur annually between May and July in the Nandi and Kericho upper parts of the Nyando river basin after long rains, with the only exception being during the 1997/98 El Nino phenomenon which occurred at the end of 1997 and early in 1998, and was followed by a malaria epidemic. An upsurge in water borne diseases like diarrhoea that normally coincides with flooding in the lower part of the Nyando river basin was also noted.

An issue that came up during the interview process was that conditions like vomiting and fever were independently reported. Discussions with the district public health officer confirmed to us that many people could not identify the difference between the symptoms of common ailments. These results are similar to those of a study carried out by Few et al. (2005:18) in Vietnam in which respondents were not able to tell the difference between dengue fever and other common fevers.

To deal with the diseases, respondents made use of both traditional 38 (8\%) and modern 490 (92\%) medicines. Self-treatment was common practice noted amongst slightly less than a quarter 98 (21\%) of the respondents. A good number of respondents acknowledged buying drugs from shops and drug stores to treat themselves without testing what they were suffering from. It was only when a member of the household was gravely ill that appropriate medical care was sought. This behaviour is consistent with the findings of Few et al. (2005:17) in Vietnam and can be attributed to low levels of health education.

Despite serious damage to housing and property, few households $22(4.7 \%)$ reported direct loss of human life. Many of the deaths reported were as a result of drowning and injuries resulting from walls, the roof of houses and trees collapsing on the victims. Most of these deaths were blamed on flash floods.

The most common response in dealing with loss of crops in both and high and low risk areas was to wait for the next season to plant. Households received seed donations from the government or borrowed seeds to plant from relatives, neighbours and friends. Respondents reported that they reduced the magnitude of crop loss by planting fast maturing crops. Some households switched from growing vegetables and maize and instead resorted to planting rice, 
others opted to renting land on higher ground to avoid expected future losses while others resorted to other businesses to supplement income. Some families in the high risk areas sold livestock to buy seeds and only $1(1 \%)$ household in both risk levels reported having put aside seeds in anticipation of such a crisis in the future. To cope with loss of pasture the highest percentage of households moved their livestock to higher ground while others travelled long distances to look for fodder for their animals. Other coping actions included replacing what had been lost, treating livestock and selling weak and vulnerable animals before the onset of floods.

Generally speaking, no respondents from the two risk levels displayed high levels of preparedness. There are several reasons why the respondents may have been unwilling to prepare for disasters. One reason is the dyke under construction. This is a highly visible measure that may have generated perceptions of a flood free area and may have largely contributed to reduced motivation to prepare. Another postulated reason is that an individual's expectation of damaging disaster does not necessarily lead to preparedness, suggesting that the sense of being at risk does not in itself move people to action (Turner et al., cited in Finnis, 2004:9). In a similar study, Kaiser (2007:4) indicated that no correlation existed between personal experience and precautionary actions and that knowledge about the risk does not automatically imply knowledge about the consequences or precautionary actions.

Vulnerable people individually and collectively develop their own means, resources and strategies to cope with flooding. All of these mechanisms, however, have financial, social and/ or opportunity implications (ISDR, 2004:42-43). To some extent results in Nyando followed the same trend with a slightly higher percentage of respondents in the low risk areas 168 (63.6\%) reporting their coping actions to be more effective as compared with those in the high risk areas 150 (56.8\%). Low income levels and repeated destruction of assets, which function as a buffer, may have compromised the ability to respond appropriately to subsequent floods.

\section{Demographic influences on coping action}

Findings from this study indicated a highly significant association between preparedness and level of effectiveness of coping action in both low and high risk levels at $\left(\mathrm{X}^{2} 52.822 ; \mathrm{df}=9 ; p=.000\right)$ and $\left(\mathrm{X}^{2} 31.833 ; \mathrm{df}=9 ; p=.000\right)$, respectively. The practical implication of these findings is that preparedness raises participant's levels of confidence in their ability to cope with flood risks.

It is generally accepted that there is a decreasing perception of hazard with age. The explanation for this was that older people may consider themselves less vulnerable due to their increased experience (Beringer, 2000:4). To a certain extent the results for the Nyando District did follow this trend with respondents in the $40+$ age categories reporting significantly lower levels of preparedness as compared with the younger age groups. Additionally, the 60+ age group had the lowest percentage of those who felt their coping actions were effective.

As regards gender, the women reported considerably lower levels of preparedness $119(40 \%)$ as compared with their male counterparts 127 (55\%). These findings are similar to those of a 
study carried out in the Pine Lake, Alberta area, Ontario (Murphy et al., 2005:83-109), in which men appeared to dominate in both outdoor and indoor preparedness. This could be attributed to low income and education levels that may have reduced the women's coping choices. These results also confirm findings of a study by Mitchell et al. (2007:4-9) which indicates that although climate change affects everyone, it is not gender neutral. Climate change magnifies existing inequalities, reinforcing the disparity between women and men in their vulnerability to and capability to cope with climate change. The same would be implied for the income category in which respondents in this study with incomes in the 10,000+ Kenyan Shilings (Kshs.) categories reported being better prepared and their coping actions more effective as compared with respondents in lower income levels. It is interesting to note that respondents who had higher education levels reported less effectiveness of their coping action as compared with people with lower education levels. This could be due to a lack of appreciation of local coping strategies. According to Faupel and Styles (1993), an explanation for this could be that education raises the participants' levels of expectations regarding what they should have been able to accomplish.

\section{External Support}

The prevailing emergency relief policy guidelines of the Kenyan Government require that local authorities provide basic necessities such as food, shelter and medical care to disaster victims. In this study, 166 (62.9\%) of respondents in the high risk areas received external support while a smaller proportion $98(37.4 \%)$ received assistance in the low risk areas. Government disaster programs accounted for a huge proportion $448(85.2 \%)$ of the support received, while 115 $(28.1 \%)$ of the respondents received help from non-government organisations. A mere 35 (6.7\%) were assisted by relatives, friends, church organisations and private donations from well wishers. Despite receiving relief support the majority of the respondents in both high and low risk areas felt the aid was insufficient and inappropriately (corruptly) handled and distributed. They were therefore forced to resort to household level adjustments to compensate for damages caused by the floods.

One of the major concerns was the extent to which respondents were able to cope without external aid. Findings from the study revealed that the majority of the respondents living in the high risk areas felt they would not be able to cope with future floods in the absence of external support. Those who received external support in both high and low risk areas reported significantly higher levels of dependence, $p=0.026$ and $p=0.003$, respectively, compared with those who did not receive support. Further results revealed that length of residency was the only demographic variable that was found to be highly significantly associated with the attitude of the respondents towards external support in the high risk areas $\left(X^{2}=69.096 ; \mathrm{df}=24\right.$; $p=0.000$ ). Confidence in ability to survive without external aid increased as the length of residency increased.

A key issue emerging was the extent to which relief measures and programs were able to strengthen the resilience of the communities to floods. Findings from the study revealed that most relief agencies were offering emergency supplies, but were reluctant to invest in the predisaster and post-disaster phases. The main explanation for this was lack of funding for longterm projects. Key informants also felt the government sponsored food-for-work program was 
creating a dependency syndrome. Activities that were previously undertaken by community members on a voluntary basis were now being performed in exchange for food. When food supplies delayed or ran out, the people refused to continue working.

\section{Conclusion}

Results demonstrate that traditional flood knowledge does exist in the study area and the strategies in such knowledge are a trusted source of information and importance to this community, which indicates some ability of the locals to be resilient. The findings revealed a greater level of awareness of flood hazards in the high risk areas in comparison with the low risk areas. They also demonstrate significant clear spatial differences in the level of awareness and use of traditional flood knowledge among respondents living in the high risk community. These were influenced by demographic variables such as age, occupation, education and length of residency.

Perception of risk is influenced by several variables, most notably past experience of major floods and having survived them. There exists an excess of confidence in structural measures which has made the residents underestimate the impact of accumulating risk and biased the decision-making process.

Significant distinctions can be drawn between the high and low risk areas. Residents in the high risk areas had significantly higher levels of awareness and use of traditional flood knowledge. They were more aware of the nature of the flood-related health risks they were exposed to and appeared better prepared for future flood risk but were more dependent on external aid. On the other hand, residents living in the low risk areas reported better success with their response mechanisms. The demonstrated differences were undoubtedly attributable to the degree of exposure to the health hazards and socio-demographic influences.

The burden of diseases was significantly higher during the flood season but the advantages of living in a flood plain seem to outweigh the health risks associated with flooding. The result is a combination of innovative adjustability and passive acceptability of potential hazards. Most of these indigenous actions were taken at the household level to adapt to the health risks posed by floods. The dependency syndrome and its pitfalls for creating less resilient communities as a result of aid dependency in disasters have contributed to decreased ability to cope as well as contributing to livelihood insecurity. This puts the focus sharply on the management and distribution of development aid in this area and the impacts of these programs on the livelihoods of beneficiaries. Deficiencies particularly of institutional capacities to implement disaster risk reduction measures at all administrative levels shed light on the risk context of the area and how vulnerability is complicated by increasing exposure to other risks such as HIV, poverty, and illiteracy, among others.

\section{Recommendations for implementation}

The following are recommendations for future planning and implementation:

Existing traditional flood knowledge is largely underutilised in the current flood management strategies. Programs promoting the use of traditional flood knowledge 
should be encouraged in order to exploit the local resources. It should also be noted that traditional flood knowledge on flood forecasting cannot function independently. It needs to be supported by official flood warning methods and a wider range of support and flood risk management measures.

- The Nyando community needs to shift from the current perceptions and preference for 'hard' defences that are costly to implement. They should instead embrace nonstructural measures that are low cost and have low maintenance requirements that are ultimately more sustainable. This, however, does not necessarily diminish the importance of structural measures; rather it points to the necessity of combining structural and non-structural measures in a way that minimises loss and achieves the greatest results.

- There is a need to strengthen the capacity of extension services like Community Health Workers (CHWs) to create awareness and to promote food security, water and environmental sanitation and health services within the community. This can be done by ensuring that there is a sufficient supply of medicines for flood-related illness and more water treatment products.

- People should be assisted in accessing information on both modern and traditional medicines for the treatment of water-related diseases. There is also a need to extend clean water and sanitation services to all households and to emphasise the key importance of good environmental health.

- Results from this study bring into sharp focus the management and distribution of development aid in the study area and the impacts of such programs on the livelihoods of beneficiaries. At present, most of the efforts of those concerned with disaster management in the Nyando District are focused either on emergency health preparedness or post-emergency relief. There is a need to have a shift in the national and international mindset, from reaction and charity to anticipation and pre-emption.

- Social differentiation in the perception of risks and socio-cultural and economic barriers to effective coping and take-up of interventions, highlight the need for health promotion and flood warning activity to be tailored to local social contexts.

- The concept of vulnerability reduction through socio-economic interventions at community level has not yet entered the mainstream discussion at government level. Deficiencies particularly of institutional capacities to implement disaster risk reduction at all administrative levels shed light on the risk context of the area and how vulnerability is complicated by increasing exposure to other risks such as HIV, poverty and illiteracy. As such, an overall improvement of incomes and the general living standards of households would go a long way in improving flood management in the study area.

- The potential of climate change to intensify or alter flood patterns means that it is likely to become a major additional driver of future health risk from flooding. The community should be encouraged to understand the importance of global climate and improve their indigenous coping strategies. 


\section{References}

ADEGU, D. 1999. Rainfall-Runoff modelling of the Nyando catchment, Kenya, Using Satellite (CCD) data. Delft: Integrating the Healthcare Enterprise. (Thesis - M.Sc.)

BERINGER, J. 2000. Community fire safety at the rural/urban Interface: the bushfire risk. Fire Safety Journal, 35(1):1-23, Jul.

BHATTA, B.R. 1999. Rehabilitation of degraded lands. (In Bhatta, B.R., Chalise, S.R., Myint, A.K. \& Sharma, P.N., eds. Recent concepts, knowledge, practices and new skills in participatory integrated watershed management. Kathmandu: Participatory Watershed Management Training in Asia (PWMTA). p. 51-68) [also available at http://books.icimod.org/demo/index.php/downloads/pd/246].

BHATTI, A. 2001. Risk perception, culture and communication: South Asian Experience. (Paper presented at the Fifth Conference of the European Sociological Association, Helsinki, 28 Aug.-1 Sept. 2001.) [also available at http://dscrn.crc.ensmp.fr/cms/uploads/esa2001/bhattiriskperceptioncultureand communication.pdf]

CANNON, T. 2000. Vulnerability analysis in disasters. (In Parker, D. ed. Floods. London: Routledge. p. 43-55.) [also available at www.radixonline.org/resources/cannon-floods-chapter.doc].

EITEL, B. \& OCHOLA, O. 2006. Integrated flood hazard, risk and vulnerability assessment in Nyando Basin, Kenya: options for land use planning. [Web:] http://www2.geog.uni-heidelberg.de/ physio/forschung/nyandobasin.htm [Date of access: 4 Jan. 2010].

FAUPEL, C. \& STYLES, S. 1993. Disaster education, household preparedness and stress responses following Hurricane Hugo. Environment and Behaviour, 25(2): 228-249, Mar.

FEW, R., AHERN, M., MATTHIES, F. \& KOVATS, S. 2004. Floods health and climate change: A strategic review, Tyndall Centre. Working Paper 63.

FEW, R., AHERN, M., MATTHIES, F. \& KOVATS, S. 2005. Health and flood risk: A strategic assessment of adaptation processes and policies. Tyndall Centre for Climatic Change Research; Technical report 17; project T3.31. University of East Anglia (UEA). [Web:] http://ceh.resourcehub.ssrc.org/ health-and-flood-risk-a-strategic-assessment-of-adaptation-processes-and-policies/resource_view [Date of access: 26 Mar. 2010].

FINNIS, K. 2004. Creating a resilient New Zealand; Can public education and community development campaigns create prepared communities? An examination of preparedness motivation strategies. Wellington: Ministry of Civil Defense \& Emergency Management. [Web:] http://www.nzrt.org.nz/ documents/finnis_report_final.pdf [Date of access: 4 Jan. 2010]

GASTON, A.S. 2005-2006. Advocating the adoption of challenging, modern approaches to disaster risk reduction to facilitate the sustainable development of vulnerable communities, Tanzania. Unpublished report: ProVention Research \& Action Grants project.

ISDR (International Strategy for Disaster Reduction). 2004. Living with risk: a global review of disaster reduction initiatives. Hyogo: United Nations, International Strategy for Disaster Reduction. 588 p.

ITDG-Bangladesh (Intermediate Technology Development Group-Bangladesh). 2003. An attempt on application of alternative strategies for community based flood preparedness in South-Asia (Bangladesh) [Web:] http://www.unisdr.org/eng/public_aware/world_camp/2003/english/Others/Bangladesh.pdf [Date of access: 30 May 2009].

JICA (Japan International Cooperation Agency). 2007. The development study for regional development programme in Nyando and Homa-Bay districts in the Republic of Kenya, Final Report Appendixes Vol.1/2. Tokyo: International Cooperation Agency. 
KAISER, G. 2007. Disaster Reduction in Climate Change; Coastal Vulnerability to Climate Change and Natural Hazards. [Web:] http://www.Cedim.de/download/39_Kaiser.pdf [Date of access: 6 Jan. 2010]

KENYA. 2006/7. State of Environment Report 2006/7, Kenya. [Web:] http://www.nema.go.ke/index2.php?option=com_docman\&task=doc_view\&gid=201\&Itemid=35 [Date of access: 14 Dec. 2009].

KENYA. Ministry of Finance and Planning. 2002. District development plan, 2002-2008: effective management of sustainable economic growth and poverty reduction. Nairobi: Government Printer.

KUHLICKE, G.C. 2006. Knowledge, Ignorance and Vulnerability; The 2002 Flood in Eilenburg (Saxony, Germany). [PowerPoint presentation]. http://www.ehs.enu.edu/file.php?id=171 [Date of access: 14 Mar. 2009].

KUNDZEWICZ, Z.W. 1999. Flood protection - sustainability issues. Hydrological Sciences Journal, 44(4):567-571, Aug.

MBARIA, J. 2006. Linking research to extension for watershed management: The Nyando experience, Nairobi: World Agroforestry Centre (ICRAF). 62 p. [also available at http://worldagroforestrycentre. org/water/downloads/publications/Nyandobook.pdf]

MILLER, N.L. 2009. Climate vulnerability assessments of water utilities in the Lake Victoria Basin. (Paper presented at the Stockholm World Water Week on 17 August 2009. Stockholm. [also available at http://www.worldwaterweek.org/documents/WWW_PDF/2009/monday/K21/NLMillerWWW17Aug09.pdf]

MINISTRY of Finance and Planning see KENYA. Ministry of Finance and Planning

MITCHELL, T., THOMAS T. \& KATTIE, L. 2007. We know what we need: South Asian women speak out on climate change adaptation. Johannesburg/London: Action Aid. [also available at http:// www.reliefweb.int/rw/lib.nsf/db900sid/PANA-79DK4C/\$file/actionaid_nov2007.pdf?openelement]

MUGENDA, O.M. \& MUGENDA, A.G. 1999. Research methods: quantitative and qualitative approaches. Nairobi: Acts Press

MUNGAI, D., SWALLOW, B., MBURU, J., ONYANGO, L. \& NJUI, A., eds. 2004. Proceedings of a workshop on reversing environmental and agricultural decline in the Nyando River Basin. World Agro-Forestry centre, the National Environment Management Authority of Kenya, The Water Quality Component of Lake Victoria Environment Management Programme (LVEMP), and the Ministry Of Agriculture and Rural Development. [Also available at http://www.worldagroforestry.org/downloads/ publications/PDFS/pr14285.pdf]102 p.

MURPHY, B., FALKNER, L., McBEAN, G., DOLAN, H. \& KOVACS, P. 2005 Enhancing local level emergency management: the influence of disaster experience and the role of households and neighbourhoods, Institute for Catastrophic Loss Reduction Paper\#43 [also available at http://iclr.org/images/ Enhancing_local_level_emergency_management.pdf [Date of access: 20 Feb. 2009].

MWAURA, P., ed. 2008. Indigenous Knowledge in Disaster Management in Africa. Nairobi: United Nations Environment Programme. 118 p.

NETHENGWE, N.S. 2007. Integrating participatory GIS and political ecology to study flood vulnerability in the Limpopo Province of South Africa. Morgantown: West Virginia University. (Dissertation - PhD in Geography). 227 p.

NJOGU, A.K. 2002. An intergrated river basin planning approach - Nyando case study in Kenya. (In Sustainable use of water resources: Papers read at the First WARFSA/WaterNet Symposium held in Maputo, Mozambique. Maputo. p. 1-11.) [also available at http://hdl.handle.net/1834/1293] 
OLCZYK, M.E. 2004. Flood risk perception in the Red River Basin, Manitoba; Implications for hazards and disaster management. Winnipeg: University of Manitoba. (Thesis - M.Sc.) 232 p.

ONGOR, D. 2007. Integrating water resource management and flood management: A community participatory approach. A case study of the Nyando river watershed in Kenya. Catchment and Lake Research, 6:50-55

ONGWENYI, G.S., DENGA, F.G.O., ABWAO, P. \& KITHEKA, J.U. 1993 Impacts of floods and drought on the development of water resources of Kenya: case studies of Nyando and Tana catchments. (In Gladwell, J.S., ed. Hydrology of warm humid regions: proceedings of the Yokohama symposium 1315 July 1993, Yokohama, Japan. Tokyo: The Foundation of River and Basin Integrated Communications p. 117-123.)

ONYANGO, L., SWALLOW, B. \& MEINZEN-DICK, R. 2005. Hydronomics and terranomics in the Nyando basin of Western Kenya. (In Van Kloppen, B., Butterworth, J. \& Juma, I., eds. African water laws: plural legislative frameworks for rural water management in Africa. Proceedings of a held in Johannesburg, South Africa, 26-28 January 2005. Pretoria: IWMI. p. 229-245) [also available at http:// www.nri.org/projects/waterlaw/AWLworkshop/All_papers.pdf]

OTIENDE, B. 2009. The economic impacts of climate change in Kenya: riparian flood impacts and cost of adaptation. [Web:] http://kenya.cceconomics.org/kedo/kenya-riparian-floods-case-study.pdf [Date of access: 13 Dec. 2009].

SALICK, J. \& BYG, A. 2007. Indigenous peoples and climate change. [Web:] http://www.tyndall. ac.uk/publications/Indigenouspeoples.pdf [Date of access: 13 Dec. 2009].

SERA PROJECT (Strengthening emergency response abilities). 2000. Vulnerability Profile: Darra Woreda (district), North Shewa Zone, Oromiya Region. Disaster Prevention and Preparedness Commission (DPPC); United States Agency for International Development (USAID). [Web:] http:// www.dppc.gov.et/downloadable/Sera\%20project/Darra\%20Woreda\%20VP.pdf [Date of access: 13 Dec. 2009].

SHARMA, D. 2002. Coping strategies and early warning systems of tribal people in India in the face of natural disasters: case studies in Maurbhanj, Orissa and Dungarpur, Rajastan, India. New Delhi: International Labour Office. 54 p.

SLOVIC, P., FISCHHOFF, B. \& LICHTENSTEIN, S. 1979. Rating the Risks. Environment, 21(3):14-39, Apr.

SWALLOW, B., ONYANGO, L. \& MEINZEN-DICK, R. 2005. Catchment property rights and the case of Kenya's Nyando basin. (In Swallow, B., Okono, N., Achouri, M. \& Tennyson, L., eds. Preparing for the next generation of watershed management programmes and projects. Proceedings of the African Workshop, Nairobi, 8-10 October 2003. Watershed management and sustainable mountain development working paper no. 8. Rome: FAO)

WANJOHI, D.M. 1999. Water flow and quality modelling of the Nyando River in Kenya. Delft: Integrating the Healthcare Enterprise. (Thesis - M.Sc.)

WIEST, R.E., MOCELLIN, J.S.P. \& MOTSISI, D.T. 1994. The needs of women in disasters and emergencies. Winnipeg: University of Manitoba. $92 \mathrm{p}$.

YAMANO, T. \& JAYNE, T. 2002. Measuring the impact of prime-age adult death on rural households in Kenya. Staff Paper 2002-26. Department of Agricultural Economics. East Lansing: Michigan State University. 